\title{
The Image of The Inter-American Court of Human Rights as an Agent of Democratic Transformation: A Tool of Self-Validation ${ }^{1}$
}

\section{La imagen de la Corte Interamericana de Derechos Humanos como agente de transformación democrática: una herramienta de autovalidación}

\author{
Natalia Torres Zuñiga ${ }^{2}$ \\ Norwegian Centre for Human Rights, University of \\ Oslo (Noruega) \\ ORCID: https://orcid.org/0000-0002-0541-1082
}

Recibido: 15-01-2020

Aceptado: 18-08-2020

\begin{abstract}
This paper provides a critical analysis of the premises and arguments put forward by the Ius Constitutionale Commune en America Latina project to ground the image of the Inter-American Court of Human Rights as an agent of democratic transformation. It highlights three critical aspects: 1. the profile of the Court is constructed by legal scholars relying on self-validation and selfreferentiality, 2. that image validates the idea that lawyers and the judiciary are agents of transformation ruling over local spaces from above, thereby discarding people as the central subjects of change and democratization, and 3. the concept of representative democracy becomes a device that secures the self-validating dynamics of the image of the Court as democracy builder.
\end{abstract}

\footnotetext{
${ }^{1}$ Este artículo se ha realizado en el marco del proyecto de investigación "Jueces en democracia: La filosofía política de la Corte Interamericana de Derechos Humanos", financiado por el Ministerio de Economía y Competitividad del Gobierno de España (DER2016-79805-P).

2 (n.torreszuniga@gmail.com) Natalia Torres Zuñiga has a Ph.D. in Law from the University of Oslo and is a guest researcher at the Norwegian Centre for Human Rights, University of Oslo. Among other things, she published: El control de convencionalidad de las normas constitucionales (EAE, Saarbrücken. 2015); "Control de normas constitucionales por la Corte Interamericana de Derechos Humanos”, en Santolaya, P. y Wences, I. (coords.), La América de los Derechos (Madrid, Centro de Estudios Políticos y Constitucionales, 2016).
} 
Key-words: Democratic Transformation, Representative Democracy, Self-Validation, Self-Referentially, Progress, International Human Rights Judiciary, Equality.

\section{Resumen}

Este artículo analiza críticamente las premisas y argumentos del proyecto Ius Constitutionale Commune en América Latina que perfilan a la Corte Interamericana de Derechos Humanos como un agente de transformación democrática. El artículo plantea tres críticas en concreto: la imagen de la Corte es una construcción llevada a cabo por los abogados y jueces que adolece de problemas de autorreferencialidad y autovalidación; 2 . En la medida que dicha construcción valida la idea de que los abogados y jueces son agentes de transformación, también descarta perspectivas que sitúan a los individuos como los sujetos que lideran la democratización de sus ámbitos locales; 3 . el concepto de democracia representativa que fundamenta la imagen de la Corte como agente de transformación democrática es una herramienta de auto-validación de la labor de esta última.

Palabras-clave: transformación democrática, democracia representativa, autovalidación, autorreferencialidad, progreso, Tribunales Internacionales de Derechos Humanos, igualdad.

\section{Introduction}

This article analyzes the premises of the Ius Constitutionale Commune en America Latina (ICCAL) project, which profiles the Inter-American Court of Human Rights (IACtHR) as an agent of democratic transformation. The project is supported by the Max Planck Institute for Comparative Public and International Law in Heidelberg, Germany, and brings together legal scholars from Latin America with a background in constitutional law, current IACtHR judges, and practitioners aspiring to become future IACtHR judges.

The group's legal scholars depict the IACtHR as a judicial agent promoting democratic transformation through human rights protection. Protecting the right to vote and the right to freedom of expression, prohibiting amnesty laws, and defending identity groups who face discrimination, exclusion, and poverty are cited as ways in which the Court promotes democracy in the Latin American region. More concretely, case law established in legal disputes such as Gelman vs. Uruguay (prohibiting amnesty laws) and Saramaka vs. Surinam (ensuring prior consultation for indigenous and Afro-descendant people) are defined as landmark decisions creating progressive, transformative standards. 
The Court is thus presented as a necessary and central agent for democratizing Latin America and advancing the rule of law.

This profile of the Court as a human rights tribunal and agent of democracy mirrors one side of an ongoing debate concerning the role of the local and international judiciary as democracy builders. Recent legal scholarship has focused on whether international tribunals enhance democracy, and multiple relevant academic publications point to the subject's topicality. Faith is increasingly placed in local and international courts as guardians of the new democratic dispensation (Daly 2017: 101-102). International human rights tribunals' role of effecting democratic transformation is taken as natural or self-evident because they represent an evolutionary stage in the nature of international law. Studies tend to describe these tribunals as agents of democratization because they protect democracy and human rights, which in turn ground the universal principle of the rule of law that currently governs international law and national legal orders.

The fairly recent image of the IACtHR as democracy builder challenges traditional understandings of the role of the international judiciary and international human rights bodies. This image of the Court implies that it is more than a dispute-settlement agent solving individual complaints related to human rights breaches. It rests on the premise that the Court has transformed from a tribunal that has an authority based on states' consent to an apolitical guardian with authority stemming from a natural and neutral notion of ius constitutionale commune.

The IACtHR's democracy-building image is far from uncontestable, however, and several questions should be asked about how objective the premises for such image actually are. In this article, I aim to argue that embracing this image of the Court is a political act through which legal scholars and practitioners self-validate and reproduce a vertical relationship between the Court and national legal orders. I will point out how this self-validation flaw is directly linked to the self-referentiality of the concepts of democracy and progress that ground the discourse of the ICCAL project and the case law of the IACtHR.

The article is divided into four parts. The first lays out a non-functionalist view of law as a discipline and explains how this approach helps in revealing the democracy-builder image of the IACtHR to be a social construction. The second and third sections describe the practice of the Court and the arguments of the ICCAL project in order to show the dynamics of self-validation (selfunderstanding and self-interpretation) and how they fit together in portraying the Court as an agent of democratization.

The fourth section demonstrates how the Court's validation of its own image emerges from the adoption of unjudged transcendental validators 
(Aspremont 2018) as if they were natural and apolitical — namely representative democracy and human rights. I aim to show how the legal discourse on the role of the Court as democracy builder obscures the political nature of the content given to concepts such as a democracy and human rights, while positing judges, lawyers, and the law as the central subjects qualified to provide democratic transformation.

\section{The Role of Lawyers and Judges: Why does it Matter?}

My critique of the self-validation and self-referentiality in legal discourses portraying the IACtHR as a democracy builder is based on the idea that the law is a set of practices and discourses carried out and operated by legal experts in particular contexts (Meerssche, 2017: 461; Sinclair 2017). That is, this article eschews the functionalist perspective of international law, ${ }^{3}$ in which the role of international institutions is always necessary, abstract, neutral, and oriented toward exclusively pursuing tasks for the good of humankind and the will of the states (Sinclair 2016: 968-969).

The non-functionalist perspective allows me to point out at least two aspects of the production of law. First, focusing on how legal actors or legal communities and international institutions shape law involves discarding the idea of law's neutrality, while accepting that as a practice it requires deploying a strategy oriented toward lawyers' empowerment while they perform as judges, activists, experts, and so on (Meersche 2017: 471; Nonet and Selznick 2001: 57). Studies that take this approach pave the way to a more reflective understanding of how lawyers and experts portray themselves and international legal institutions as agents of change, emancipation, or transformation (Megret 2012). ${ }^{4}$ Generally, focusing on the role of legal experts or legal communities in making law leads us to establish a connection between law as a profession and the production of global governance (Kennedy 2008).

I will argue that the image of the IACtHR as an agent that promotes democracy is the product of interaction between legal professionals-scholars and judges-who discuss, study, and struggle over the very nature and future

\footnotetext{
${ }^{3}$ According to Klabbers, the functionalist approach to international law understands "international organizations as entities created to execute functions through specifically conferred powers, delegated to them by their member states" (Klabbers 2014). In this account, states give international tribunals the mandate to pursue justice and their competences are always apolitically deployed in that direction.

${ }^{4}$ To illustrate, some scholars argue that the European Court of Justice (ECJ) and its profile as a supra-constitutional tribunal is the product of the legal actors' interactions and the deployment of diverse strategies to cast it as the constitutional interpreter of European Union treaties. It is stated that legal networks around the ECJ have elevated decisions such as Van Gend en Loss vs Nederlandse Administratie der Belastingen - related to the doctrine of direct effect - to the function of a material constitution far more robust than the treaties themselves (Cohen \& Vauchez 2011).
} 
of the Court. These actors bring together imaginaries that manifest in an array of standards, principles, and concepts-such as democracy, human rights, and courts - that support the growth and eventual expansion of the competences of the IACtHR to shape our local political orders (Meersche 2017: 471; Sinclair 2017). Adopting a non-functionalist perspective means assuming that the image of the Court as a democracy builder, rather than a free-floating entity, is the result of a symbolic process of generating common beliefs among these actors (Cohen \& Vauchez 2011). This symbolic process puts the law at the center of conflict situations. It is a political action that paradoxically consists of depoliticizing the role of experts in shaping the understanding of democracy and human rights in the region by portraying those concepts as self-evident and apolitical.

Self-validation asserts international law without demonstrating its rational authority (Purvis 1991). Self-referential and apparently self-evident arguments related to the nature of international law and its sources, or the apolitical origins the international institutions, dictate their own formation without justification through external factors or elements. The self-image of the IACtHR as democracy builder thus results from the self-referential argument that international tribunals are apolitical actors whose interpretations provide or give content to human rights and representative democracy, as abstract truths that precede differentiality, relationality, and history - in other words, as natural and apolitical rule of law.

The self-validating portrayal of the IACtHR as an agent of democratic change in itself may create relations of domination between the international judiciary and local political orders. Self-referential arguments validate the image of the Court and lawyers as agents of transformation, while downplaying the agency of other people (Schlag 1990).

The self-validation process, as mentioned, is the result of the dynamics of self-understanding and self-interpretation that are operated by legal professionals, scholars and judges. ${ }^{5}$ Analyzing how self-understanding and self-interpretation function can help delineate how the legal discourse around the IACtHR, rather than emerging from the belief system of a state or states, results from the belief system of a community of professionals (Apresmont 2018) who continually portray the law and their role as lawyers as pivotal elements for transformation (Kennedy 2016).

${ }^{5}$ I am indebted to Stein Bolstad Skjelbred for the argument on self-understanding and selfinterpretation between the Court and the ICCAL project.

Araucaria. Revista Iberoamericana de Filosofí, Política, Humanidades y Relaciones Internacionales, año $23, \mathrm{n}^{\circ} 46$. Primer cuatrimestre de 2021. Pp. 483-504. ISSN 1575-6823 e-ISSN 2340-2199 https://dx.doi.org/10.12795/araucaria.2021.i46.24 


\section{Ius Constitutionale Commune in Latin America and the Dynamics of Self-Validation}

The ICCAL project is part of a legal network whose vision of the IACtHR as a democracy builder is a tool for the legal profession's self-validation. Rodiles points out that ICCAL "is evidence of 'law as profession,' that is, of a project of influential Latin American constitutionalists (scholars and judges) who, as globalization advances, have come to embrace the internationalization of their field, as well as European international lawyers with a (German) constitutionalist and comparatist mindset" (Rodiles 2018). Scholars who are part of the project share spaces of debate at annual meetings in several Latin American cities, as well as at workshops in Heidelberg organized by the Max Planck Institute. They also frequently publish articles and books related to the existence of a ius commune as part of the ius constitutionale commune project. $^{6}$

ICCAL is founded on the idea that international tribunals are agents of global governance, with transformative powers and a democratic legitimacy to act on behalf of people (Bogdandy 2015). The project describes itself as a legal approach with the main goal of promoting the transformation of Latin America through law (Bogdandy and others 2017). Scholars supporting ICCAL argue that the judiciary plays a key and indeed pivotal role in the democratization of Latin American states.

One premise of the project is that the transformation of the Latin American democracies, or the advancement of their democratic principles, requires the intervention of the international structures and, more concretely, of the IACtHR. ICCAL depicts the IACtHR is an agent of governance that builds standards and principles that constitute a sort of ius constitutionale commune for Latin America, that is, a material constitution that is binding for the region.

ICCAL's notion of ius constitutionale commune posits standards of human rights protection and the adoption of the representative democratic principle as essential for realizing human rights in the Latin American region (Bogdandy and others 2017). The idea is that the judiciary can forge a new culture of cooperation based on respect for democratic values of pluralism, human rights, and democracy (Skouteris 2015). Thus ICCAL supports the idea, created by the Court itself, that the Court's decisions have general complianceinducing effects, as well as the idea that the Court holds the last word on human rights protection in the region. The role of the Court in creating a culture of democracy is possible due to the nature of its decisions and its function as ultimate interpreter of the ius constuitutionale commune (Bogdandy and others 2017).

${ }^{6}$ In 2017, the Max Planck Institute and Oxford University Press jointly released a collective book on ICCAL's emergence, introducing its tenets and perspective.

Araucaria. Revista Iberoamericana de Filosofia, Politica, Humanidades y Relaciones Internacionales, año $23, \mathrm{n}^{\circ} 46$. Primer cuatrimestre de 2021. Pp. 483-504. ISSN 1575-6823 e-ISSN 2340-2199 https://dx.doi.org/10.12795/araucaria.2021.i46.24 
Studying the premises of the ICCAL project is crucial for demonstrating that the interaction it facilitates between legal scholars and Court judges triggers a self-validation process (Purvis, 1991) whereby legal actors become the experts or moral agents that carry out Latin America's democratization and transformation (Sinclair 2015: 748-749). As will be shown, this self-validation stems from the fact that the ICCAL discourse rests on the uncontroversial narrative that ius constitutionale commune is an apolitical, universal idea that transcends the beliefs of the members of the legal community. That is, a narrative that is self-referential and speaks for itself (Skouteris 2010).

For the IACtHR and its judges, self-validation occurs through the interaction of the dynamics of self-understanding (through the case law of the Court) and self-interpretation (through the ICCAL legal scholars). Current judges of the Court, such as Ferrer Mac-Gregor, and former judges, such as Garcia Ramirez, participate in ICCAL activities and share their imaginaries and ideas with the other constitutional lawyers that perform as local judges and those aspiring to become IACtHR judges. These dynamics mean that scholars and the Court both affirm the latter's authority as an agent that promotes democracy without necessarily presenting an argument for or demonstrating how they arrive at this conclusion.

The following sections demonstrate how the case law of the Court reproduces the self-understanding of its judges concerning its role as democracy builder, and how the work of ICCAL scholars further reproduces this image.

\section{Case Law of the IACTHR on Human Rights and Democracy: Self Understanding as a Democracy Builder}

The case law of the IACtHR grounds its self-understanding as a democracy builder. The Court has embraced a concept of representative democracy linked to the protection of civil, political, and economic, social, and cultural rights. Specifically, it reproduces the contents of the American Convention on Human Rights (ACHR) and the Inter-American Democratic Charter on the concept and scope of a model of representative democracy.

The Court refers to the notion of representative democracy as the "determining factor throughout the system of which the ACHR is a part." "In its view, representative democracy is a condition for the effectiveness and realization of human rights in the region. The IAtCHR has reinforced this idea, stating that achieving the rights recognized in the ACHR must be based on "effective exercise of representative democracy," which results in

\footnotetext{
${ }^{7}$ IACtHR. The Word "Laws" in Article 30 of the American Convention on Human Rights. Advisory Opinion OC-6/86 of May 9, 1986. Series A No. 6.
} 
popularly elected, legally created organs, respect for minority participation, and furtherance of general welfare. ${ }^{8}$

The Court has established a connection between democracy as a set of procedures that necessarily contributes to the achievement of rights, such as access to justice, and substantive equality. It has reproduced this notion of representative democracy in connection to the right of freedom of expression (Last Temptation of Christ vs. Chile), amnesty laws (Gelman vs. Uruguay), political rights, equality, and democracy (Yatama vs. Nicaragua), rights to property and equality (Saramaka vs. Surinam and Kalina Londono vs. Surinam), and the rights of judicial authorities and democratic institutions (Constitutional Tribunal vs. Peru). The idea that representative procedural democracy is a prerequisite for advancing the protection of human rights is explicit in the 2008 decision Castaneda Gutman vs. Mexico, for example. Then, the Court stated "that the effective exercise of political rights is an end in itself, while at the same time constituting a fundamental means whereby democratic societies guarantee the other human rights inscribed in the Convention."

While affirming the necessity of democratic procedures to secure rights such as access to justice and equality, the Court defines itself as the agent that settles the limits of democratic procedures taking place at the local level. For example, in cases related to the invalidity of amnesty laws and to protecting collective property and the right to prior consultation, it positions itself as having the final say on protecting democracy and human rights in the region.

The 2001 case Gelman vs. Uruguay demonstrates Court practice related to the limits that human rights impose on the democratic principle. In that case, the Court declared the incompatibility of the Expiry Law, granting amnesty to the perpetrators of gross violations of human rights in Uruguay that happened during the dictatorial period in the 1970s and 1980s), with inter-American standards for human rights protection. The Court rejected arguments pointing out that the Expiry Law has been approved by a democratic parliament and confirmed through two referenda. Instead, it stated that a democratic norm must meet norms for human rights protection. In its opinion, the Uruguayan amnesty exceeded the forum of what is "possible to be decided" by a majority, as human rights protection constitutes an "impassable limit" to majority rule; thus the approval of the amnesty law was in breach of the ACHR. The arguments used by the Court rested on the idea that the prohibition of amnesty laws is a norm of ius cogens corresponding to a universal obligation to secure access to justice for victims of gross violations of human rights. The Court also provided arguments related to the general effects of its decisions, and stated that Uruguay's legislation breached its previous case law, such as Barrios Altos vs. Peru and

${ }^{8}$ IACtHR. Case of Castañeda Gutman v. Mexico. Preliminary Objections, Merits, Reparations, and Costs. Judgment of August 6, 2008. Series C No. 184.

Araucaria. Revista Iberoamericana de Filosofia, Politica, Humanidades y Relaciones Internacionales, año $23, \mathrm{n}^{\circ} 46$. Primer cuatrimestre de 2021. Pp. 483-504. ISSN 1575-6823 e-ISSN 2340-2199 https://dx.doi.org/10.12795/araucaria.2021.i46.24 
Almonacid Arellano et al vs. Chile, in which the Court declared amnesty laws to be incompatible with the Inter-American Human Rights System. ${ }^{9}$

In this case, the democratic pedigree of the amnesty law appears as invalid justification before the strength of a universal norm, created or discovered by the Court, that prioritizes criminal prosecution over alternative modes for reconciliation. The Court chose a formalistic perspective that positions abstract rules above a more contextualized analysis of the validity of amnesty laws in democratic contexts. Indeed, a pertinent question here is whether this choice voided the concept of democracy as the will of people. Another question is to what extent the Court could prove the existence of a universal rule that prohibits amnesty laws, even in democratic contexts, without relying on self-explanation or self-referencing (Aspremont 2018).

The Court also developed arguments concerning the connection between representative democracy and the protection of the rights to equality and property in Saramaka People vs. Suriname (2007) and Kalina Londono vs. Suriname (2017). For the Court, realizing the collective dimension of the right to property was found to involve guaranteeing the right to prior consultation of indigenous people and Afro-descendants. Concretely, the state must ensure the effective participation of indigenous and Afro-descendant groups concerning any development, investment, exploration, or extraction plan that may conflict with their right to collective property or put at risk their physical and cultural survival. In Kalina and Londono vs. Suriname, the Court explicitly referred to the link between the principle of democracy and indigenous groups and Afrodescendants' right to prior consultation. ${ }^{10}$

In the Court's view, effective participation through democratic procedures -the right to prior consultation- is necessary to overcome inequalities and the exclusion of disadvantaged groups such as indigenous peoples and Afrodescendants. Its reasoning focused on the protection of the right to collective property and subsequent equality through adopting certain quality standards in the proceedings and securing the access and participation of disadvantaged people. The problem here is that the Court paints itself as the transformative democratization agent solely through the idea that it has provided concrete standards that secure the effectiveness of prior consultation. The idea that the standards for prior consultation created by the Court are proof of its role as an agent of democratic transformation clearly has self-explanatory and self-

\footnotetext{
${ }^{9}$ IACtHR. Case Gelman v. Uruguay. Merits and Reparations. Judgment of February 24, 2011 Series C No. 221.

${ }^{10}$ The Court has also drawn a clear relation between democracy and equality and nondiscrimination. In the Yatama vs. Nicaragua, it noted that the states must secure the right to political participation of indigenous and Afro-descendant people. For the Court, the fact that Nicaragua did not admit the forms of association other than political parties breached the rights to equality and political participation of the indigenous regional political movement Yatama (not a political party) from participating in municipal elections.
} 
referentiality flaws. It forecloses several important questions, such as: To what extent does access to democratic proceedings enable Afro-descendants and indigenous people to overcome the root causes of structural inequalities affecting them? To what extent does access to democratic proceedings imply real democratization? And to what extent is the Court entitled to the last word on the model of democracy that guarantees the effectiveness of human rights?

\section{ICCAL and the Image of the IACtHR as an Agent of Democratization: Self-Interpretation}

In order to depict the Court as an agent that promotes democracy and transformation, legal scholars involved in the ICCAL project have used the case law above. In doing so, they build and support a narrative in which IACtHR decisions have necessarily contributed to protecting human rights and democracy, in order to strengthen the rule of law in Latin America. This involves the exercise of adopting a specific notion of democracy, identifying certain cases, defining them as landmark decisions, and reproducing their contents as examples of progress and democratization. The notion of democracy adopted by ICCAL coincides with the Court's understanding of itself, drawn through its case law, as a democracy builder. It also reflects the dynamics of selfinterpretation that, together with the act of self-understanding, self-validate this particular image of the Court.

Like the Court, ICCAL scholars define democracy as a set of rules applicable to electoral proceedings for electing political authorities, as well as participatory methods. These scholars also state that the principle of democracy encompasses substantive elements such as material equality and distributive justice, among others. For them, a combination of democracy and material equality helps overcome some of the flaws of the liberal model of the state that does not necessarily achieve real equality and freedom (Clerico 2011: 141).

This conception of democracy as a set of political proceedings is posited in opposition to the historical period in which dictatorships ruled Latin American political communities, specifically in the 1980s. Because the ICCAL account rests on factual events such as the end of Latin American dictatorships, the start of democratic procedural rule, and new constitutions that put the individual and individual dignity as the end of the legal discipline, it is apparently incontestable. Just like the Court, ${ }^{11}$ ICCAL legal scholars refer to mass violations of human rights and the deployment of Condor Operation as proof of the region's dark historical stage. In their view, that period of darkness has been overcome through the rise of representative democracy as a principle

\footnotetext{
11 See Gelman vs. Uruguay and references to Condor Operation.
} 
of government in Latin America and the subsequent strengthening of national democratic institutions and international organizations (Bogdandy and others 2017).

ICCAL scholars point out that the Court played a pivotal role during the democratization period of the late 1980s and 1990s. They cite its role in upholding a prohibition of amnesty laws as an example of its contribution to bolstering the stability of the new democracies. The argument is that criminal prosecution, by a democratic state, of the perpetrators of human rights abuses is the only way to sustain the process of democratization.

These scholars reject the possibility that the Court could have eventually applied the notion of the margin of appreciation or deference in favor of states with democratic governments. ${ }^{12}$ For them, the prohibition on amnesty laws constitutes a universal limit to democratic governments, and that universality stems from the fact that the Court holds the last word on human rights protection in Latin America. For example, former Judge Ferrer Mac-Gregor has stated that the state parties to the ACHR must follow the IACtHR on human rights without exception. Similarly, Judge Garcia Ramirez, who is also an ICCAL member, has argued that the Court's decisions have general effects. The image of the Court as the last interpreter of the ACHR is sufficient to support Court decisions and validate its limitations on majoritarian democracy.

ICCAL scholars also state that advancing the democratic principle requires overcoming the exclusion, inequality, and corruption present in various Latin American countries (Bogdandy and others 2017). They have used the Saramaka case to develop the idea that the Court's jurisprudence on the right to prior consultation constitutes high standards to be adopted by states (Herrera 2017). Equally, Clerico has stated that its case law on the rights of indigenous people to consultation and to property contribute to advancing a democratic rule of law in Latin America. For Clerico, this case law helps overcome structural inequalities that have historically affected indigenous and Afro-descendant people (Clerico 2011: 141). It therefore helps consolidate the model of representative democracy.

In the ICCAL view, Court decisions on participatory methods favoring indigenous and Afro-descendant people are inherently transformative or necessarily contribute to securing their rights. These decisions are seen as pivotal for combatting structural inequalities, and therefore for strengthening the concept of democracy. Moreover, their arguments to justify the prohibition of amnesty laws build the idea that the Court has become a social engineer acting on behalf of a general interest that transcend national borders (Skouteris 2010).

${ }^{12}$ For some authors and local authorities, Court decision breached the democratic majoritarian principle (Gargarella 2015).

Araucaria. Revista Iberoamericana de Filosofia, Politica, Humanidades y Relaciones Internacionales, año $23, \mathrm{n}^{\circ} 46$. Primer cuatrimestre de 2021. Pp. 483-504. ISSN 1575-6823 e-ISSN 2340-2199 https://dx.doi.org/10.12795/araucaria.2021.i46.24 


\section{A Critique of the Profile of the IACtHR as an Agent Promoting Democracy and Democratic Transformation}

The self-understanding and self-interpretation dynamics that ground the image of the Court as an agent of democratization are non-objective. That is, they reflect a particular way of interpreting Latin American history and a faith in the legal discipline - particularly judges - as a weapon of change, improvement, enlightenment, and transformation. This way of thinking is based on a narrative of progress mirrored in the use of phenomena such as the adoption of democratic rule, the judicialization of human rights violations, and the functioning of international institutions as proofs of progressive transformation in the Latin American context (Skouteris 2010).

The narrative of the ICCAL project describes the competence of the Court as a democracy builder as inevitable, desirable, and necessary to confront chaos in Latin America (Kennedy 2008). This is implied when ICCAL scholars state that the IACtHR, the local judiciary, and their interpretations have become central to improved rights protection and enhanced procedural democracy. These arguments, together with Court case law, carry the flaw of self-validation because they apparently speak for themselves. They portray the concept of procedural democracy and the expansive role of the judiciary per se as selfevident proof of progress in opposition to violence (Altwicker and Diggelmann 2014).

Arguments that the Court is a democracy builder reveal their reliance on self-evidence when they find its existence and democracy-building competence as legitimate due to the values it protects or the general effects of its decisions. None of the reasons given for the definition of the Court as a democracy builder can be proved or explained through external arguments. These arguments and reasons are imparted as truths that do not need empirical demonstration.

The doctrine of the general effects of the Court's case law suffers from the same flaw, since neither the Court nor ICCAL scholars can prove it without referring to the idea that human rights validate these erga omnes effects. Indeed, human rights protection seems to explain, in itself, a sort of evolution in the doctrine of sources of international law, as it does not initially recognize the general effects of judicial decisions. In its self-referentiality, human rights protection as an argument discards, or has no need for, the doctrine of sources of international law to justify the nature of Court decisions. ${ }^{13}$ The notion of human rights as shaped by the Court and the idea that the Court is the authoritative interpreter of the ACHR appear to need no further explanation since what validates these ideas is belief.

${ }^{13}$ Space is lacking here to discuss the self-referentiality of the doctrine of sources of international law and human rights.

Araucaria. Revista Iberoamericana de Filosofia, Politica, Humanidades y Relaciones Internacionales, año $23, \mathrm{n}^{\circ} 46$. Primer cuatrimestre de 2021. Pp. 483-504. ISSN 1575-6823 e-ISSN 2340-2199 https://dx.doi.org/10.12795/araucaria.2021.i46.24 
Likewise, ICCAL scholars argue that the profile of the Court as a democracy builder stems from the principles and moral rules it is supposed to protect, such as human rights and democracy. Here, representative democracy and human rights are natural and neutral concepts that do not need explanation. The problem with supporting this belief as a truth is that it requires overlooking the fact that the contents or meaning given to both concepts always involve political choices (Marks 2000) that endorse their own self-referentiality.

Such arguments do however lead to empowerment of legal experts as agents of transformation or as social engineers, since they act on behalf of those values. Their reliance on self-evidence precludes several inquiries about the model of representative democracy and its potential for transformation, such as whether it sufficiently fulfills the idea of democracy as the will of people and a vehicle for self-determination.

The self-validating aspect of the Court's role as a democracy builder is the result of the self-referentiality inherent within three premises grounding that image, which I will go on to discuss: 1, the interdependence between democracy and human rights adopted by the IACtHR and reproduced by ICCAL; 2, the universality of the prohibition of the amnesty laws; and 3, the role of the Court in promoting equality and therefore democracy. ${ }^{14}$

\subsection{Self-validation and the uncontested relation between representative democracy and human rights}

Defining the role of the Court in terms of democracy building necessarily means adopting a specific perspective on the concept of democracy itself, the notion of democratic transformation, and the role and functions of international structures in promoting democracy.

For ICCAL scholars, the consensus around the principle of participatory or representative democracy and its co-originality with human rights are not up for discussion. Accepting this link and reproducing it implies that these scholars have adapted to a new order in which representative democracy is equivalent to progress. They have embraced this consensus as something neutral or given.

Lawyers' portrayal of themselves as agents of democratization in procedural terms is grounded in political adjustment (Shklar 1986). They describe interdependence between human rights and democracy as a natural step following the end of the Latin American dictatorships. ${ }^{15}$ Both the Court and ICCAL have defined this procedural, representative model of democracy

\footnotetext{
${ }^{14}$ In this article I discuss the problems of self-validation in the notion of representative democracy embraced by the Court and ICCAL scholars, so the self-referentiality of the Court's decisions themselves are not a direct object of analysis.

${ }^{15}$ A parallel can be traced with the arguments raised by Slaughter and Teson around the idea that a worldwide revolution of liberal democracy occurred after the end of the Cold War (Marks 2003).
}

Araucaria. Revista Iberoamericana de Filosofia, Política, Humanidades y Relaciones Internacionales, año $23, \mathrm{n}^{\circ} 46$. Primer cuatrimestre de 2021. Pp. 483-504. ISSN 1575-6823 e-ISSN 2340-2199 https://dx.doi.org/10.12795/araucaria.2021.i46.24 
as the only one with transformative potential in the Latin American context. In the view of ICCAL project, it is the only one that represents progress and the end of violence.

By reducing the alternatives for change or progress to a duality between dictatorships and representative democracy, ICCAL scholars do not consider whether this notion of democracy might actually not be transformative, or whether it masks its own dark sides or shortcomings. They support the representative democracy model without asking themselves what democracy means in real terms, or what the model's limits and the limits of human rights protection in the framework of democratic procedures might be.

Specifically, there is no discussion about a concept of democracy, beyond low-intensity participatory, deliberative, or representative models, that posits people as its central agents. If the "will of people" is at the core of the notion of democracy, talking about democracy or human rights without reference to people means taking these notions as descriptive terms for liberal societies as they are today. Thus democracy becomes a set of rules and procedures, and discussions focus on the consolidation of those rules and procedures, while the oppressed remain excluded and indeed subject to the domination of rules imposed by hegemonic powers. Discarding the notion of people, or not discussing it as the core element of democracy, implies that procedural democracies are ends in themselves. Although it is not the object of this article to discuss the notion of people, ${ }^{16}$ it is important to reflect on whether the abovementioned models of democracy are real weapons that allow people to define the social, economic, and political aspects of their lives and pursue real emancipation.

Similarly, the definition of human rights and its relationship to procedural democracy have not been contested among ICCAL scholars. For them, as in the case law of the Court, the only possible setting for realizing human rights is procedural representative democracy. Accepting this idea implies a conception of human rights that dismisses their radical nature. Instead of looking at human rights as a demand for a different way of being together, or for a rupture with oppressive political and economic powers, ICCAL embraces a procedural democracy that reduces human rights realization to access to and quality of procedures (Wall 2012).

Defining the IACtHR as a builder of a procedural model of democracy empowers legal actors and leaves other agents of change - such as "ordinary" people - as passive empty vessels in need of institutional aid. Since, with ICCAL's support, the Court has positioned itself as the authoritative interpreter on human rights protection that sets limits for representative democracies, it is imposing a model of human rights and democracy that may eventually fail to

${ }^{16}$ People are neither an entity out of time nor a stable and unitary entity. For a further analysis see Wall 2012.

Araucaria. Revista Iberoamericana de Filosofia, Política, Humanidades y Relaciones Internacionales, año $23, \mathrm{n}^{\circ} 46$. Primer cuatrimestre de 2021. Pp. 483-504. ISSN 1575-6823 e-ISSN 2340-2199 https://dx.doi.org/10.12795/araucaria.2021.i46.24 
correspond to the needs of ordinary people. While representative democracy is the framework for international tribunals shaping local orders from above, it has also triggered people's loss of their role as central subjects who can redefine the scope and meaning of democracy and human rights according to their needs and circumstances. That role implies that they could eventually discard the current model of procedural democracy in favor of one that helps promote real transformation.

Moreover, through Court practice and ICCAL arguments, the procedural notion of democracy works simultaneously as an empty concept before human rights protection (Schaffer 2008), and as one in which procedures have a substantive dimension single-handedly capable of effecting transformation. Both the eventual emptiness and the substantive dimension of the concept of procedural democracy secure the position of the Court as democratization agent ruling over local political communities from above. The ambivalence between the emptiness and the eventual substantive value of procedural democracy reflects the idea that, in the end, democracy means what the Court defines as its core concept: "nothing more and nothing less than implementing a scheme of rights" (Schaffer 2008).

In the view of ICCAL and the Court, the scope of rights implementationtheir content - is defined through Court case law and the general effects of its decisions. Likewise, as the guardian of rights the Court also secures a notion of democracy whose content varies according to how best it can safeguard the position of the Court as the region's authoritative interpreter and democracy maker. The procedural democracy that is thereby reproduced ultimately empowers lawyers, creating and reinforcing a vertical relationship between the Court and local orders that breeds the former's distrust of the latter.

Last but not least, portraying the Court as an agent of procedural democracy overlooks the fact that the legal community is not a neutral actor but works in favor of the rule of law, and may play a part in reproducing economic and political machinery that create relations of domination that disempower ordinary people (Kennedy 2016). ${ }^{17}$ Indeed, the arrival of the model of representative democracy in Latin America did not emerge from thin air, but through the intervention of hegemonic powers that supported this model to reduce politics to a matter of periodic elections and depoliticize other aspects of political life, such as the economy, distribution, and means of production (Wood 1995; Robinson 1996).

The second sub-section explains how the notion of procedural democracy as applied to amnesty laws helps self-validate the hierarchical role of Court lawyers as ruling democracies from above. The third sub-section points out how providing content to the right to prior consultation is presented as sufficient

\footnotetext{
${ }^{17}$ It is not within the remit of this article to develop arguments related to how legal scholars and the law have distributive effects (linked to the dynamics of the world political economy).
} 
remedy to overcome the problems of indigenous and Afro-descendant people with regards to their right to collective property.

\subsection{Self-validation and emptiness of the notion of democracy: Distrust over Latin American democracies (amnesty laws)}

In the view of the Court and ICCAL scholars, democratization means a uniform rule on the prohibition of amnesty laws, as in Gelman vs. Uruguay. No democratic procedure - even a referendum - can counter this understanding.

The notion of democracy as a set of democratic procedures was emptied in Gelman. It was found to mean nothing before the overwhelming force of human rights and criminal prosecution in post-conflict societies. Human rights disqualify any decision taken by the people, such as through a referendum, to approve of amnesty laws. The position of the Court and ICCAL on the prohibition of amnesty laws as a general or universal rule overlooks the complexity of transitional processes in post-conflict societies. It reduces alternative paths for such transitions to the prosecution and punishment of the perpetrators of human rights violations. Stating that the prohibition of amnesty laws is a norm of ius cogens, as the Court did in Barrios Altos, entails depoliticizing a highly contestable issue by reducing it to the existence of an abstract legal universal norm defined by judges and applicable to any context.

The ICCAL perspective on prohibiting amnesties rests on the idea that local democracies or majorities are unruly, possibly ineffective and inequitable, and not to be trusted (Sinclair 2017). When ICCAL scholars argue that the IACtHR decision in Gelman vs. Uruguay or in Barrios Altos vs. Peru was correct, they assert that judges and legal scholars, that is, legal experts, are better positioned to act on behalf of human rights and protect democracy against its own flaws. In positioning lawyers and the law above agents such as ordinary people, they hold that law is neutral and transcends politics (Veçoso 2012; Shklar 1986).

Establishing a uniform approach to the prohibition of amnesty laws, prevailing over any specific historical and political context, requires selfvalidation in the ICCAL discourse. Here, law and the formality of its rules are self-referential. For ICCAL scholars no argument can refute the rule prohibiting amnesties: Since the Court has stated the universality or even the ius cogens nature of that rule, it must be accepted as a truth, regardless of what ordinary people have decided by themselves. A highly contestable moral problem is treated as a question of expertise and know-how that is manageable by legal experts (Sinclair 2017).

Some scholars have tried solving this vertical definition of the Court as a democracy builder by suggesting the notion of the margin of appreciation as a method by which the Court can restrain itself. This would not necessarily 
overcome the self-referential flaw in this definition of the Court, however, for stating that the Court should have provided deference (a margin of appreciation) to Uruguay due to the quality of its representative democracy (Contesse 2017) implies that the quality of democracy is to be measured by the criteria of a group of judges within an international tribunal. The acts of rejecting or embracing the margin of appreciation are not substantially different, since both fit with the idea that procedural democracy is an issue that should be discussed among judges.

When the sense of democracy is shaped in this way, people participating in democratic proceedings become passive subjects whose agreements on transitional justice must accommodate the decisions of an international tribunal on which they are not represented. Again, we see a vertical understanding of Court authority as building democracy from above. However, the most questionable aspect here is that voiding democracy to support a uniform prohibition of amnesty laws epitomizes the self-image of lawyers who believe that transformation and democratization is effected by sophisticated moral rules plucked from the air or constructed from above (Aspremont 2015)

\subsection{Self-validation and substantive procedural democracy: The IACtHR promoting equality}

ICCAL's lawyers and particularly its judges bestow on themselves the image of solvers of political and economic problems (Charlesworth 2002) such as poverty and structural inequality. In the ICCAL narrative, current Court case law engages with ends, such as distributive justice, that are the goals following the stabilization of democracies in a post-dictatorial context. As discussed, ICCAL scholars depict the right to prior consultation as the procedural tool that provides the opportunity for inclusion and transformation to indigenous and Afro-descendant people (Herrera, 2017). In their view, the standards created by the Court for procedural democracy help disadvantaged groups overcome material inequality and exclusion (Clerico 2011; Gargarella 2018).

The arguments through which ICCAL scholars insist on the importance of procedural mechanisms also rely on self-validation and self-evidence. First, procedural democracy again positions the Court as the agent that establishes the standards or core content of the right to prior consultation. In the ICCAL narrative those standards - such as the requirement that the consultation process is culturally adequate - have been crucial in protecting the rights of the abovementioned groups. Yet even when, as in this case, the concept of democracy has content rather than appearing empty, references to it are used to justify the image of the Court as the authority on how a democratic procedure such as prior consultation should be fulfilled. 
When scholars state that the Court is a thriving democracy builder solely because it has created the standards of the right to prior consultation, the flawed reliance on self-evidence is clear. In fact, adopting a procedural approach to democracy as the only method to reach equality or inclusion arguably deprives people of genuine participation in the decisions affecting their lives (Marks 2003: 66).

Embracing this image of the Court also requires overlooking the fact that the right to prior consultation may not necessarily impede the implementation of extractive or investment projects. Indeed, some scholars point out that, regardless of the right to prior consultation, alternative methods have helped indigenous people prevent extractive projects being implemented (Zaremberg and Torres Wong 2018). Such proposals shift the focus of attention away from the achievements of the Court and toward people as the main agents of change.

Focusing on procedural rules does not necessarily ensure that people can discuss substantive issues related to the material conditions of their lives. In practice, the effectiveness of the procedure depends on the organizational capacity of the groups in question, on their capacity to reject investment projects, ${ }^{18}$ and eventually on their capacity to discard the use of prior consultation. Further, linking procedural democracy to indigenous people's access to the right to property overrides the possibility of connecting human rights battles with alternative political and economic models of distribution.

The reliance of the ICCAL discourse on self-evidence is likewise seen in its idea that the current model of procedural democracy is ahistorical. It posits procedural rules as not serving any interests, such as those of lawyers, but also as if they were not relational and situational to political and economic powers (Ryan 1980). In working in a way that favors a model of procedural democracy, ICCAL scholars reinforce the idea that solutions to issues such as poverty and inequality are ultimately to do with the effectiveness of proceedings.

As Rodiles states, there are many reasons to view the concept of rule of law — human rights and democracy — as serving the most militarily, politically, and economically powerful. Instead of engaging with this criticism, the ICCAL project has embraced a notion of law that that serves its own professional interests (Rodiles 2018). Going forward, ICCAL scholars must consider the possibility that procedural democracy may contribute to maintaining an economic and political system that creates poverty. They must no longer overlook the fact that procedures do not necessarily provide the possibility for real transformation or for challenging the root causes of misery.

18 Torres Wong has stated that realizing the right to prior consultation in all cases related to Peru, Bolivia, and Mexico ultimately resulted in indigenous approval for the projects (Zaremberg and Torres Wong 2018).

Araucaria. Revista Iberoamericana de Filosofia, Politica, Humanidades y Relaciones Internacionales, año $23, \mathrm{n}^{\circ} 46$. Primer cuatrimestre de 2021. Pp. 483-504. ISSN 1575-6823 e-ISSN 2340-2199 https://dx.doi.org/10.12795/araucaria.2021.i46.24 


\section{Conclusions}

In this article, I have argued that the image of the Court as a democracypromoting agent is a social construction resulting from dynamics of selfunderstanding and self-interpretation among legal scholars and IACtHR judges who take part in the ICCAL project. This social construction suffers from a reliance on self-validation and self-evidence that is directly connected to the progress narrative grounding the notion of ius constitutionale commune as procedural democracy and human rights.

Portraying the Court as a necessary agent that promotes representative procedural democracy means asserting that the only way toward progress or change at the local level involves adopting that model of democracy and ensuring that international institutions rule over representative democracies from above. These are political choices that disempower people as the main actors of change and rules out the notion of self-government from below.

Indeed, the article has demonstrated how procedural democracy becomes a concept whose content is indeterminate. In the ICCAL reasoning and the case law of the Court, the final notion of democracy is dependent on a concept of human rights protection that privileges criminal prosecution and legal formalities as solutions for inequality. This understanding of the relation between democracy and human rights secures the vertical positioning of the Court as an agent of expertise with the last word on democracy and human rights in the region.

The analysis of the self-validation strategies of the ICCAL project and Court judges begs a pending question about the role legal experts play in securing the domination of economic and political powers over people. Perhaps the ICCAL project, in adopting a notion of procedural democracy, is currently more conservative than transformative. To recover the idea of popular rule that is at the core of democracy as well as the radical nature of human rights, we lawyers must debate the idea of representative democracy rather than accepting it as a self-evident.

The arguments I have raised here do not aim to invalidate the IACtHR or deny its achievements in human rights protection. The intention, on the contrary, is to compel my colleagues to look at the law and its institutions in more instrumental terms, discarding the idea that they are ends in themselves. Equally, I invite them to reflect on the limitations of our discipline in promoting democracy, change, and progress; to look at human rights and democracy more critically, rather than assuming that they are always inherently revolutionary, apolitical, universal, and good. 


\section{Bibliography:}

Aspremont, J. D'Aspremont, "Jus Cogens as a Social Construct without Pedigree." Netherlands Yearbook of International Law 46, (2016): 85114.

Aspremont, J. D'Aspremont, International Law as a Belief System (Cambridge, 2018).

Altwicker \& Diggelmann, T. Altwicker and O. Diggelman, "How Is Progress Constructed in International Legal Scholarship?", European Journal of International Law 25.2 (2014): 425-44.

Bogdandy, A. v., "Ius Constitutionale Commune en América Latina: Observations on Transformative Constitutionalism", AJIL Unbound (109): 109-114. doi:10.1017/S2398772300001264.

Bogdandy A. v., E. Ferrer Mac-Gregor, M. Morales Antoniazzi, and F. Piovesan (eds.), Transformative Constitutionalism in Latin America: The Emergence of a New Ius commune (Oxford, 2017).

Cohen and A. Vauchez, "The Social Construction of Law: The European Court of Justice and Its Legal Revolution Revisited", Annual Review of Law and Social Science 7.1 (2011): 417-31.

Contesse J., "The final word? Constitutional dialogue and the Inter-American Court of Human Rights: A rejoinder to Paolo Carozza and Pablo González Domínguez." International Journal of Constitutional Law 15(2): 443 446. doi:10.1093/icon/mox036.

Clérico, L. Ronconi and M. Aldao, "Hacia la reconstrucción de las tendencias jurisprudenciales en América Latina y el Caribe en materia de igualdad: sobre la no-discriminación, la no-dominación y la redistribución y el reconocimiento." Revista Direito GV 9(1) (2013): 115-170. doi:10.1590/ S1808-24322013000100006.

Charlesworth H. "International Law: A Discipline of Crisis", Modern Law Review 65.3 (2002): 377-92.

Daly T. G., The Alchemists: Questioning Our Faith in Courts as Democracybuilders (Cambridge, 2017).

Dulitzky A., "When Afrodescendants Became Tribal Peoples", UCLA Journal of International Law \& Foreign Affairs 15(1) (2010): 29-81.

Frankenberg G., Comparative Law as Critique (Edward Elgar, 2016).

Gargarella R., "The constitutionalization of international law in Latin America. Democracy and rights in Gelman vs. Uruguay." American Journal of International Law. AJIL unbound 109 (2015): 115-119.

Gargarella R., Democracy's Demands. AJIL Unbound, 112 (2018), 73-78. doi:10.1017/aju.2018.33 
Herrera J. C., "The Right of Cultural Minorities to Binding Consent: Case Study of Judicial Dialogue in the Framework of a Ius Constitutionale Commune en América Latina", Max Planck Institute for Comparative Public Law \& International Law (MPIL) Research Paper No. 201 7-11, 32.

Kennedy, D., A World of Struggle: How Power, Law, and Expertise Shape Global Political Economy (Princeton, 2018). www.jstor.org/stable/j. ctt1wf4cz3 accessed December 13, 2019.

Klabbers, J., "The Emergence of Functionalism in International Institutional Law: Colonial Inspirations", European Journal of International Law 25.3 (2014): 645-75.

Marks, S. The Riddle of All Constitutions: International Law, Democracy, and the Critique of Ideology (Oxford, 2003).

Meerssche D., "Scholars in Self-estrangement (again): Rethinking the Law of International Organisations", London Review of International Law 5.3 (2017): 455-80.

Nonet, P. and P. Selznick, Law \& Society in Transition: Toward Responsive Law (Transaction, 2001).

Purvis, N., "Critical legal studies in public international law", Harvard International Law Journal 32(1) (1991): 81-127.

Robinson W., Promoting Polyarchy: Globalization, US intervention, and Hegemony (Cambridge, 1996).

Rodiles, A., "The Great Promise of Comparative Public Law for Latin America: Toward Ius Commune Americanum?", In A. Roberts et al. (eds), Comparative International Law (Oxford 2018).

Ryan M., "Self-evidence", Diacritics (1980): 216.

Sihvo, O., "Global Constitutionalism and the Idea of Progress", Helsinki Law Review, 12(1) (2018): 10-34.

Sinclair, G. F., To Reform the World: International Organizations and the Making of Modern States (Oxford, 2017).

Schaffer, J., Democrats Without Borders: A Critique of Transnational Democracy (Gothenburg, 2008).

Schlag, P. "Normative and Nowhere to Go", Stanford Law Review, 43.1 (1990): 167-191.

Shklar, J., Legalism: Law, Morals and Political Trials (Harvard, 1986).

Skouteris, T., "The Idea of Progress", In A. Orford and F. Hoffmann (eds.), The Oxford Handbook of the Theory of International Law (Oxford, 2015).

Skouteris, T., The Notion of Progress in International Law Discourse (Asser 2010). 
Veçoso, F., Entre absolutismo de direitos humanos e história contextual: aspectos da experiencia da Corte Interamericana de Direitos Humanos (University of Sao Paulo, 2012). Doctoral degree.

Wall, I. R., Human Rights and Constituent Power: Without Power or Warranty (Routledge, 2012).

Wood, E. M., Democracy Against Capitalism: Renewing Historical Materialism. (Cambridge, 1995).

Zaremberg G. and Torres Wong, M., "Participation on the Edge: Prior Consultation and Extractivism in Latin America", Journal of Politics in Latin America 10.3 (2018): 29-58. 